\title{
Influence of different application rates of nitrogen to soil on rhizosphere bacteria
}

\author{
E. LILJEROTH, G. C. SCHELLING* \& J. A. VAN VEEN
}

Institute for Soil Fertility Research, P. O. Box 48, NL 6700 AA Wageningen, Netherlands

Received 16 February 1990; accepted 16 March 1990

\begin{abstract}
The bacterial populations in the rhizosphere of wheat were investigated with plants grown in soil at different nitrogen regimes. Nitrogen was applied to soil in different ways; two different levels of nitrogen ( $250 \mathrm{mg} \mathrm{N}$ per plant and $50 \mathrm{mg} \mathrm{N}$ per plant) were added as a single application or split in time during growth, and consequently smaller amounts were given each time. The different application methods made it possible to study the bacterial populations in relation to nitrogen concentrations in the roots and in the soil with comparable rates of plant biomass production.

When the nitrogen was applied as a single dose at the start of the experiment significantly larger total numbers of bacteria (colony forming units) were found in the rhizosphere of the plants than in the other treatments. This was correlated with higher nitrogen concentrations in the roots and with higher levels of extractable mineral nitrogen in the soil. In contrast, the numbers of fluorescent pseudomonads were smaller when a high nitrogen rate was applied once. Possible mechanisms for the observed changes in the microbial populations are discussed.
\end{abstract}

Keywords: wheat, rhizosphere bacteria, fluorescent pseudomonads, nitrogen fertilization

\section{Introduction}

The larger numbers of microorganisms present in the rhizosphere compared to rootfree soil is due mainly to the input of carbon substrates released from roots (Whipps \& Lynch, 1986). In addition, several environmental factors influence both the release of materials from roots and the microbial utilization of these root-derived materials, and hence the abundance and composition of the microorganisms in the rhizosphere (Whipps \& Lynch, 1986). Increased nitrogen fertilization has been reported to increase the numbers of bacteria in the rhizosphere (van Vuurde, 1978; Kolb \& Martin, 1988; Liljeroth et al., 1990). Other authors have reported no effect of nitrogen on bacterial populations in the rhizosphere (van Vuurde \& de Lange, 1978; Turner et al., 1985).

Increased nitrogen availability in soil could improve utilization efficiency of the

* Present address: Research Institute for Plant Protection, P.O. Box 9060, NL 6700 GW Wageningen, Netherlands. 
exudates by microorganisms (Merckx et al., 1987; van Veen et al., 1989; Liljeroth et al., 1990) since, in the rhizosphere, new carbon is continuously added by the roots in an environment where the plant and the microorganisms are continuously competing for nutrients. In these studies, plants appeared to be strong competitors for nutrients compared to the microorganisms. Since nutrients, such as nitrogen, are essential in both plant and microbial metabolism, competition for nitrogen could affect microbial carbon transformation and thus the processes ultimately linked to microbial biosynthesis and energy production.

Another reason for changes in microbial populations in the rhizosphere in response to nitrogen additions could be altered root exudation, but few studies on the effect of nitrogen on root exudation have been published. Bowen (1969) reported that loss of amino acids from the root of Pinus radiata seedlings was reduced by nitrogen deficiency but increased by phosphorus deficiency. Using ${ }^{14} \mathrm{C}$-labelling of atmospheric $\mathrm{CO}_{2}$, Liljeroth et al. (1990) found that more of the root-translocated carbon was released from wheat roots of plants grown at high soil nitrogen levels than at low soil nitrogen levels.

In this study the effects of two different levels of nitrogen fertilization on the dynamics of the bacterial populations in the rhizosphere were investigated. The nitrogen was applied in two different ways, i.e. a single application or split application. The different application methods made it possible to study the bacterial populations in relation to nitrogen concentrations in the roots and in the soil with comparable rates of plant biomass production.

\section{Materials and methods}

\section{Soil}

A loamy sand (Ede) was air-dried to $10 \%$ water content and passed through a $5-\mathrm{mm}$ sieve. Mineral nutrients and water were added; the final water content was $14 \%$ $(-25.1 \mathrm{kPa})$. Plastic pots were filled with $1.5 \mathrm{~kg}$ soil. Mineral nutrients, except nitrogen, were applied in the following amounts (mg per pot): $\mathrm{P}$ and $\mathrm{K}, 191$ and 407 , as $\mathrm{K}_{2} \mathrm{HPO}_{4} \cdot 3 \mathrm{H}_{2} \mathrm{O}$ and $\mathrm{KH}_{2} \mathrm{PO}_{4}$, respectively; $\mathrm{Cu} 3.4$ as $\mathrm{CuSO}_{4}$; B 0.8 as $\mathrm{H}_{3} \mathrm{BO}_{3}$; Mo 5.5 as $\left(\mathrm{NH}_{4}\right)_{6} \mathrm{Mo}_{7} \mathrm{O}_{24} \cdot 4 \mathrm{H}_{2} \mathrm{O} ; \mathrm{Mn} 1.4$ as $\mathrm{MnSO}_{4} \cdot \mathrm{H}_{2} \mathrm{O} ; \mathrm{Zn} 1.1$ as $\mathrm{ZnSO}_{4} \cdot 7 \mathrm{H}_{2} \mathrm{O}$; Fe 2.5 as Fe-EDTA. Half of this nutrient mixture was thoroughly mixed with the soil before filling the pots and the remaining part was added with the irrigation water after 5 weeks of plant growth. Four nitrogen fertilization treatments were used:

(I) $250 \mathrm{mg} \mathrm{N}$ per plant applied once,

(II) $50 \mathrm{mg} \mathrm{N}$ per plant applied once,

(III) $250 \mathrm{mg} \mathrm{N}$ per plant, multiple applications (split treatment),

(IV) $50 \mathrm{mg} \mathrm{N}$ per plant, multiple application.

The split treatments followed an exponentially increasing addition rate up to 48 days of plant growth as described in Table 1. The nitrogen given at the start of the experiment was thoroughly mixed with the soil together with the other nutrients; nitrogen added later was given with the irrigation water. 
Table 1. Nitrogen additions to the soil in four different treatments: high/low $\mathrm{N}$ and single/split application (mg $\mathrm{N}$ per pot as $\mathrm{NH}_{4} \mathrm{NO}_{3}$ ).

\begin{tabular}{|c|c|c|c|c|}
\hline \multirow[t]{2}{*}{ Day } & \multicolumn{4}{|l|}{ Treatment } \\
\hline & $\begin{array}{l}\text { I } \\
\text { high N } \\
\text { single appl. }\end{array}$ & $\begin{array}{l}\text { II } \\
\text { low N } \\
\text { single appl. }\end{array}$ & $\begin{array}{l}\text { III } \\
\text { high N } \\
\text { split appl. }\end{array}$ & $\begin{array}{l}\text { IV } \\
\text { low N } \\
\text { split appl. }\end{array}$ \\
\hline 0 & 250 & 50 & 0 & 0 \\
\hline 7 & 0 & 0 & 4 & 0.8 \\
\hline 14 & 0 & 0 & 5 & 1.0 \\
\hline 21 & 0 & 0 & 7 & 1.4 \\
\hline 24 & 0 & 0 & 4 & 0.8 \\
\hline 28 & 0 & 0 & 6 & 1.2 \\
\hline 31 & 0 & 0 & 9 & 1.8 \\
\hline 35 & 0 & 0 & 17 & 3.4 \\
\hline 38 & 0 & 0 & 18 & 3.6 \\
\hline 42 & 0 & 0 & 35 & 7.0 \\
\hline 45 & 0 & 0 & 37 & 7.4 \\
\hline 48 & 0 & 0 & 71 & 14.2 \\
\hline 55 & 0 & 0 & 37 & 7.4 \\
\hline Sum & 250 & 50 & 250 & 50 \\
\hline
\end{tabular}

\section{Plants and growing conditions}

Seeds of spring wheat (Triticum aestivum L. emend Thell., line C-R5B) were germinated on moist filter paper and then planted in pots (one plant per pot). The surface of the soil was covered with a layer of washed aquarium grit. Unplanted pots of all nitrogen addition treatments were prepared as controls. The moisture content of the soil was adjusted daily to $14 \%$ by weighing the pots and adding sterilized demineralized water. All pots were incubated in a growth chamber at $20{ }^{\circ} \mathrm{C}$ and a relative humidity of $70 \%$ during the day $(16 \mathrm{~h})$. During the night $(8 \mathrm{~h})$, the temperature and relative humidity were $15{ }^{\circ} \mathrm{C}$ and $85 \%$, respectively. The light intensity was approximately $650 \mu \mathrm{E} \mathrm{m}-2 \mathrm{~s}^{-1}$. After 20,27,34, 47 and 67 days of incubation, three plants of each treatment were harvested and soil samples were taken for bacterial and nitrogen analysis. Two samples per treatment were taken from the soils of the unplanted controls.

\section{Analyses}

Bacterial numbers in the rhizosphere and unplanted soil were determined with plate count methods. After separating the root system from the soil the roots were shaken free of loosely adhering soil and root samples $(10 \mathrm{~g})$ with soil still adhering, representing the whole root system, were placed in Erlenmeyer flasks containing 95 $\mathrm{ml} 0.1 \%$ sterile sodium pyrophosphate solution and $10 \mathrm{~g}$ grit and shaken on a rotary shaker for 10 minutes at $200 \mathrm{rpm}$. Tenfold serial dilutions of the suspensions 
were made with $0.1 \%$ sodium pyrophosphate and plated out on culture media. Root-free soil samples of $10 \mathrm{~g}$ were also taken and treated in the same way. When the dilutions were made the roots were removed from the Erlenmeyer flasks and washed in running tap water; root weight was determined and the actual weight of the soil used for the suspension was then calculated. Total plate counts were made on 1/10-strength Tryptic Soya Agar (TSA) (Martin, 1975) and the numbers of fluorescent pseudomonads were counted on medium S1 (Gould et al., 1985). The TSA plates were incubated for 10 days at $20^{\circ} \mathrm{C}$ while the $\mathrm{S} 1$ plates were counted after an incubation of four days at $24^{\circ} \mathrm{C}$.

Dry weights of shoots, roots and soil were determined after drying at $80^{\circ} \mathrm{C}$ to constant weight. Nitrogen contents of homogenized plant material were determined after digestion of plant material in sulphuric acid and salicylic acid. The amount of nitrogen was determined as $\mathrm{NH}_{4}{ }^{+}$with Nessler's reagent (van Ginkel \& Sinnaeve, 1980). The presence of mineral nitrogen in soil was determined by extraction of 25 g soil (two replicates per pot) with $50 \mathrm{ml} 0.5 \mathrm{M} \mathrm{K}_{2} \mathrm{SO}_{4}$ on a rotary shaker for one hour. After centrifugation at $18000 \mathrm{rpm}$ for 10 minutes, samples were taken for $\mathrm{NH}_{4}{ }^{+}$and $\mathrm{NO}_{3}{ }^{-}$analysis. Nitrogen analyses were carried out with an autoanalyzer according to van Ginkel \& Sinnaeve (1980).

\section{Statistical analyses}

A two-factor analysis of variance over the entire time of the experiment was performed with time and nitrogen treatments as the factors. Bacterial numbers were log-transformed.

\section{Results}

\section{Plant growth}

Growth of shoots and roots was similar for treatments I (high N, single application) and II (low N, single application) up to 34 days. Thereafter, the plants in treatment I grew faster. The plants given nitrogen as split applications (III, IV) grew slower up to 34 days. However, in the later stages of the experiment, the growth rates of the plants in treatment III (high $\mathbf{N}$, split application) were slightly higher than those of plants in treatment I (Table 2). Thus, growth appeared to have been limited by nitrogen supply in the early stage for the split application treatments. Plants with the high nitrogen treatment (I en II) generally had higher shoot-root ratios than plants with the low nitrogen treatments (II en IV).

\section{Plant nitrogen content}

The nitrogen concentrations in shoots and roots decreased with time $(P<0.001$, Table 3). The decrease was smaller in the two treatments with split application, i.e. III and IV, than in single application treatments, as indicated by a significant interaction between time and nitrogen treatment $(P<0.001)$. The plants in treatment 
Table 2. Dry weight of shoots and roots of spring wheat at five harvest times. Means $\pm \operatorname{SD}$ (g per plant) are given.

\begin{tabular}{|c|c|c|c|c|c|c|}
\hline \multirow[t]{2}{*}{ Day } & & \multicolumn{4}{|c|}{ Treatment ${ }^{1}$} & \multirow[t]{2}{*}{$\operatorname{LSD}(P<0.05)$} \\
\hline & & I & II & III & IV & \\
\hline \multirow[t]{2}{*}{20} & shoot & 0.56 & 0.58 & 0.47 & 0.39 & 0.11 \\
\hline & root & 0.16 & 0.17 & 0.17 & 0.17 & 0.06 \\
\hline \multirow[t]{2}{*}{27} & shoot & 1.68 & 1.54 & 1.15 & 0.71 & 0.41 \\
\hline & root & 0.55 & 0.62 & 0.56 & 0.36 & 0.24 \\
\hline \multirow{2}{*}{34} & shoot & 3.66 & 3.60 & 2.28 & 1.56 & 0.77 \\
\hline & root & 1.27 & 1.26 & 0.96 & 0.70 & 0.23 \\
\hline \multirow[t]{2}{*}{47} & shoot & 8.85 & 6.46 & 6.18 & 3.04 & 0.61 \\
\hline & root & 1.92 & 1.61 & 1.22 & 0.72 & 0.31 \\
\hline \multirow[t]{2}{*}{67} & shoot & 15.18 & 7.73 & 12.39 & 5.79 & 0.76 \\
\hline & root & 2.38 & 1.50 & 2.03 & 0.92 & 0.16 \\
\hline
\end{tabular}

I See table 1 .

I usually had higher nitrogen concentrations both in the shoots and the roots than the plants in all the other treatments. The concentrations of plant nitrogen were generally higher in treatment III than in treatment IV. In treatment II, the concentrations were initially comparable to I but decreased quickly and by the end of the experiment, the plant nitrogen concentrations were the lowest of all treatments. $\mathrm{pH}$ of the soils (bulk soil of planted pots) was measured on day 67 and only minor differences could be detected among treatments: 6.1 and 6.4 for high $\mathrm{N}$ and low $\mathrm{N}$, respectively.

Table 3. Nitrogen concentrations in shoots and roots of spring wheat (percent of plant dry weight).

\begin{tabular}{lllllll}
\hline \multirow{2}{*}{ Day } & & \multicolumn{2}{l}{ Treatment' } & & LSD $(P<0.05)$ \\
\cline { 3 - 5 } & & I & II & III & IV & \\
20 & shoot & 4.0 & 4.8 & 4.0 & 3.3 & 1.2 \\
& root & 3.9 & 3.3 & 2.5 & 2.0 & 0.4 \\
27 & shoot & 4.4 & 2.5 & 2.3 & 2.2 & 0.9 \\
& root & 3.4 & 1.7 & 1.5 & 1.7 & 0.7 \\
34 & shoot & 2.7 & 1.3 & 1.8 & 1.2 & 0.2 \\
& root & 2.8 & 1.0 & 1.3 & 1.0 & 0.3 \\
47 & shoot & 1.6 & 0.7 & 2.2 & 1.2 & 0.2 \\
& root & 1.8 & 0.8 & 1.5 & 1.0 & 0.3 \\
67 & shoot & 1.0 & 0.9 & 1.3 & 0.8 & 0.6 \\
& root & 1.5 & 0.7 & 1.7 & 1.0 & 0.3 \\
\hline
\end{tabular}

1 See Table 1. 
Table 4. Extractable nitrogen in soil at five harvest times (mg $\mathrm{N}$ per $\mathrm{kg}$ soil).

\begin{tabular}{|c|c|c|c|c|c|}
\hline \multirow[t]{2}{*}{ Day } & & \multicolumn{4}{|c|}{ Treatment ${ }^{1}$} \\
\hline & & I & II & III & IV \\
\hline \multirow[t]{2}{*}{20} & $\mathrm{NH}_{4}-\mathrm{N}$ & $47 \pm 12$ & $<2$ & $<2$ & $<2$ \\
\hline & $\mathrm{NO}_{3}-\mathrm{N}$ & $33 \pm 6$ & $9 \pm 9$ & $<2$ & $<2$ \\
\hline \multirow[t]{2}{*}{27} & $\mathrm{NH}_{4}-\mathrm{N}$ & $7 \pm 11$ & $<2$ & $<2$ & $<2$ \\
\hline & $\mathrm{NO}_{3}-\mathrm{N}$ & $84 \pm 3$ & $<2$ & $<2$ & $<2$ \\
\hline \multirow[t]{2}{*}{34} & $\mathrm{NH}_{4}-\mathrm{N}$ & $<2$ & $<2$ & $<2$ & $<2$ \\
\hline & $\mathrm{NO}_{3}-\mathrm{N}$ & $32 \pm 3$ & $<2$ & $<2$ & $<2$ \\
\hline \multirow[t]{2}{*}{47} & $\mathrm{NH}_{4}-\mathrm{N}$ & $30 \pm 3$ & $<2$ & $7 \pm 1$ & $<2$ \\
\hline & $\mathrm{NO}_{3}-\mathrm{N}$ & $5 \pm 1$ & $<2$ & $7 \pm 1$ & $<2$ \\
\hline \multirow[t]{2}{*}{67} & $\mathrm{NH}_{4}-\mathrm{N}$ & $29 \pm 2$ & $2 \pm 3$ & $25 \pm 2$ & $<2$ \\
\hline & $\mathrm{NO}_{3}-\mathrm{N}$ & $<2$ & $<2$ & $<2$ & $<2$ \\
\hline
\end{tabular}

1 See Table 1.

\section{Extractable nitrogen in soil}

The amount of extractable nitrogen in soil $\left(\mathrm{NO}_{3}{ }^{-}\right.$and $\left.\mathrm{NH}_{4}{ }^{+}\right)$was generally much larger in treatment $I$ than in all the other treatments $(P<0.001$, Table 4$)$. In treatments II and IV, extractable nitrogen was not usually detectable while in treatment III the levels increased towards the end of the experiment. At the second and third harvest, i.e. day 27 and day 34, nitrogen was mainly found in the form of $\mathrm{NO}_{3}^{-}$, while on days 47 and $67 \mathrm{NH}_{4}{ }^{+}$was also found. At the first harvest, $\mathrm{NO}_{3}{ }^{-}$and $\mathrm{NH}_{4}{ }^{+}$were found in comparable amounts.

\section{Bacteria}

In the unplanted control soil no significant differences in total colony-forming units (CFU) were found among the treatments (Fig. 1b) although the numbers of fluorescent pseudomonads found in the unplanted controls were smaller in treatment $I$ than in the other treatments (Fig. 2b, $P<0.001$ ). In the rhizosphere, however, significantly larger total numbers of bacteria were found in treatment $\mathrm{I}(P<0.001)$, while the other treatments did not differ significantly (Fig. 1a). The differences became evident after 34 days of plant growth. The numbers of fluorescent pseudomonads in the rhizosphere were, in contrast to the total CFU, lower in treatment $I$ than in the other treatments (Fig. 2a, $P<0.01$ ). The percentage fluorescent pseudomonads of the total CFU was always lower than $0.2 \%$ and decreased with time both in the unplanted soil and in the rhizosphere $(P<0.05)$ and the percentages fluorescent pseudomonads of the total CFU were significantly lower in treatment I $(P<0.05)$ than in other treatments. 

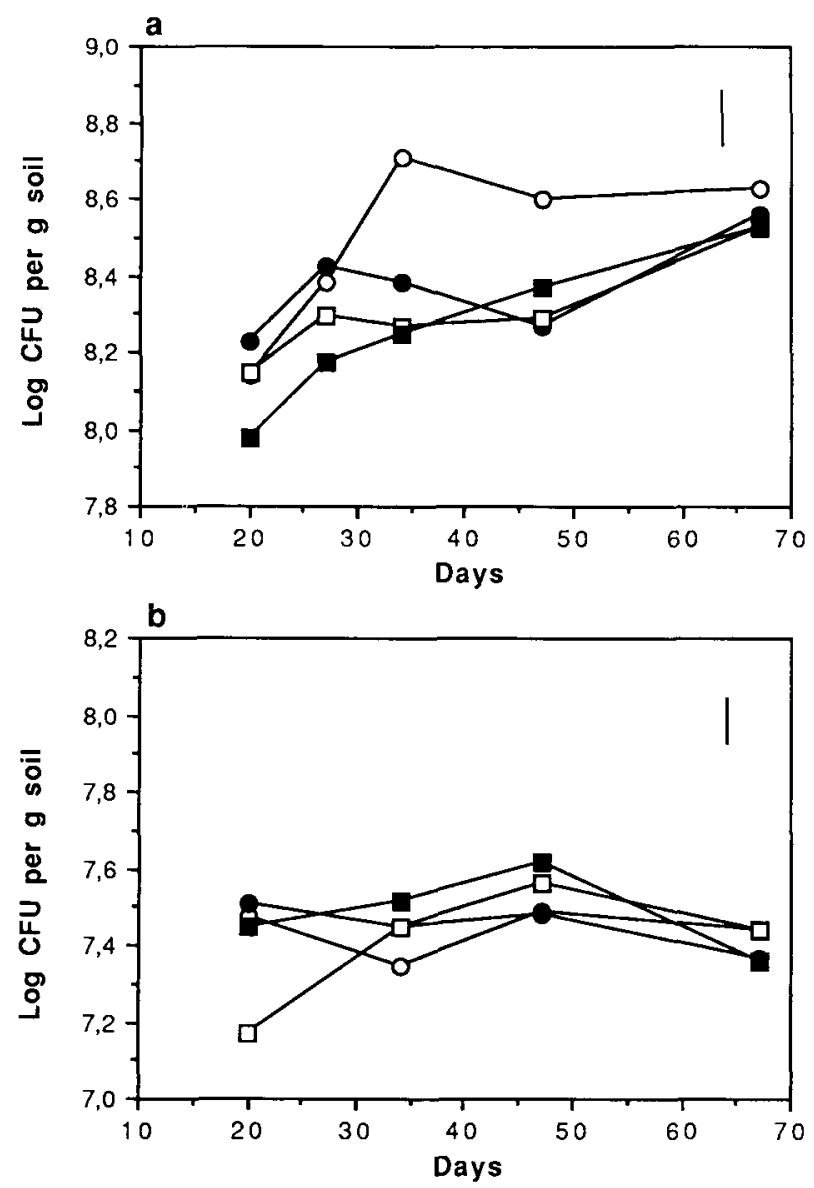

Fig. 1. Bacterial numbers (total CFU) in the rhizosphere of wheat (a) and in root-free control soil (b) at different nitrogen regimes. Symbols $-\circ-$ high $N$ single application; - $\bullet-$ low $N$, single application; - - high N, split application; - - low N, split application. Bars indicate standard deviation from ANOVA.

\section{Discussion}

The plants grew faster in treatment I, although this became only evident after 27 days. In treatment III (high nitrogen, split application), growth was slower in the beginning of the experiment, indicating nitrogen limitation. The aim of the exponentially increased addition rate of nitrogen with time in treatment III was to give the plant the nitrogen needed for growth while avoiding high soil nitrogen concentrations. It can be concluded that a higher addition rate would have been necessary for optimum growth. Nevertheless, by adding nitrogen in different ways it was possible, at least during part of the growing period, to create plants with comparable 

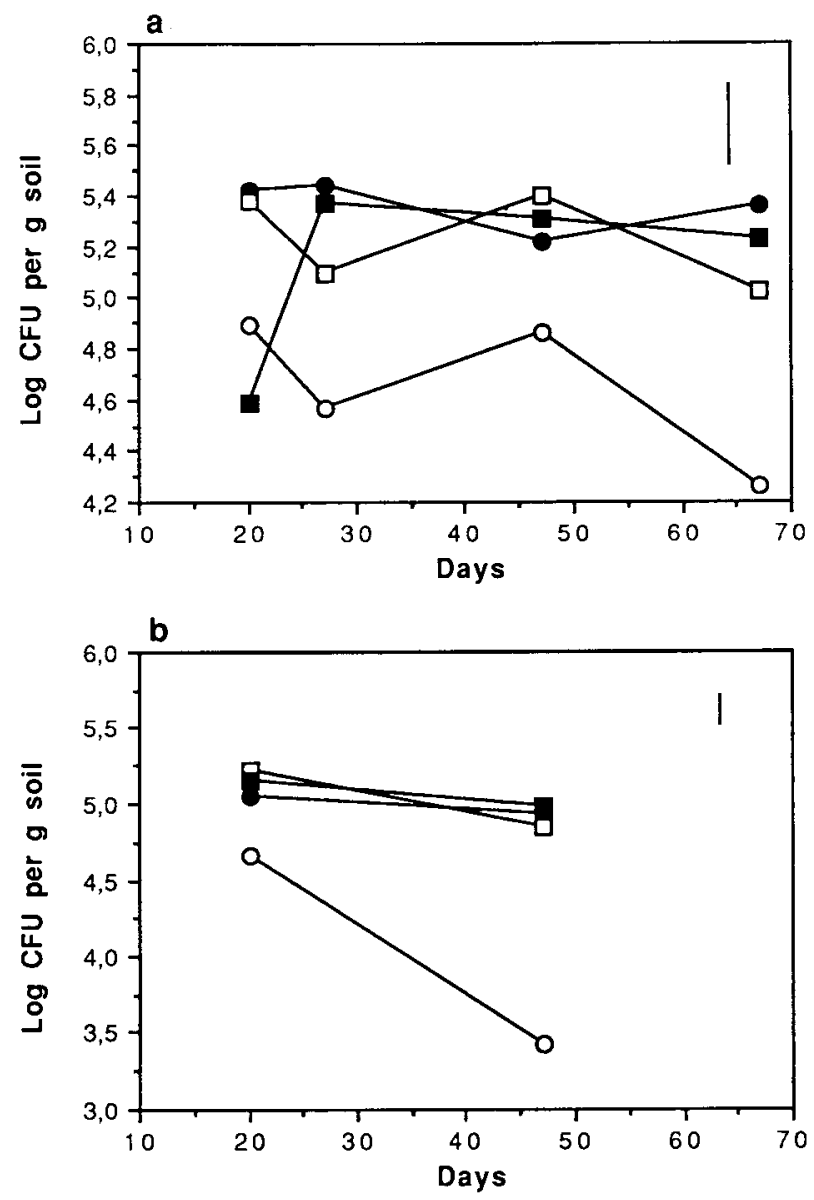

Fig. 2. Numbers of fluorescent pseudomonads in the rhizosphere of wheat (a) and in root-free control soil (b) at different nitrogen regimes. Symbols: - o - high N, single application; - $\bullet-$ low N, single application; - - high N, split application; - - - low N, split application. Bars indicate standard deviation from ANOVA.

dry weight production but with different concentrations of nitrogen both in the plants and in soil.

The total numbers of bacteria were significantly higher in the treatment in which nitrogen was applied at the higher rate in a single dose (I) than in any other treatment. In this treatment the concentrations of nitrogen were considerably higher both in the roots and in the soil during the main part of the experimental period. It is difficult to conclude from the results which mechanisms led to the higher 'total' bacterial numbers, a higher exudation rate or improved microbial utilization of the exudates, since more mineral nutrients were available (extractable) in the soil. Qualitative changes in root exudation may also have occurred. 
Recently, indications of mineral nutrient limitations of microbial metabolism in the rhizosphere have been reported (Merckx et al., 1987; van Veen et al., 1989; Liljeroth et al., 1990). In experiments where plants were grown in ${ }^{14} \mathrm{C}$-labelled $\mathrm{CO}_{2}$ atmosphere, Merckx et al. (1987) found that in a nutrient-poor treatment, a greater proportion of ${ }^{14} \mathrm{C}$ accumulated in soil after 6 weeks, and a higher percentage of the soil ${ }^{14} \mathrm{C}$ residue remained in an easily extractable (or available) form, suggesting mineral nutrient limitation for microbial growth. The decomposition of glucose, added to soil, was found to be stimulated by higher mineral nutrient levels (van Veen et al., 1989), while the decomposition rate of added straw, as measured by $\mathrm{CO}_{2}$ production, appeared to be negatively influenced by high nutrient levels. Thus, their data agree with the present results that larger amounts of available mineral nitrogen in soil stimulate microbial metabolism in planted soil.

While the total number of bacteria, counted on a relatively poor medium, were larger at higher nitrogen concentrations, the numbers of fluorescent pseudomonads were significantly smaller. This effect was evident both in the rhizosphere soil and in the unplanted control soil, indicating a direct effect of nitrogen on these bacteria. Perhaps some groups of bacteria are sensitive to high ionic concentrations. This result is contradictory to the increased numbers of fluorescent pseudomonads found by Merckx et al. (1987) in the rhizosphere of maize at a higher level of additions of mixed mineral nutrients as compared to soils to which a smaller amount of mineral nutrients was applied. However, in the latter study the actual concentrations of mineral nutrients in the soil were not measured. It is possible that the maize plants quickly took up the nutrients and that high soil concentrations occurred only during a short initial period. Besides, root-derived materials may be qualitatively different for maize and wheat. Materials released from maize contain greater proportions of simple sugars, which are readily available substrates for the metabolism of quickly growing bacteria such as fluorescent pseudomonads. Merckx et al. $(1986,1987)$ showed that root-derived products from maize were more efficiently utilized than products from wheat roots.

In a paper by Miller et al. (1990) the general behaviour of fluorescent pseudomonads was studied in the rhizosphere of two wheat cultivars. The percentages of fluorescent pseudomonads of the total numbers were always $<1 \%$ and decreased significantly with time. Further, the percentages were lower in the rhizoplane than in the rhizosphere soil. A similar decrease with time was observed here and generally the percentages were even lower in the rhizosphere soil than in the root-free soil. These results indicate that fluorescent pseudomonads are not the most rhizosphere-competent group of bacteria since other groups of bacteria apparently increase in numbers and as a percentage of the total populations proposed by Miller et al. (1990).

\section{References}

Bowen, G. D., 1969. Nutrient status effects on loss of amides and amino acids from pine roots. Plant and Soil 30: 139-142. 


\section{E. LILJEROTH, G. C. SCHELLING AND J.A. VAN VEEN}

Ginkel, J. H. van \& J. Sinnaeve, 1980. Determination of total nitrogen in plant material with Nessler's reagent by continuous flow analysis. Analyst 105: 1199-1203.

Gould, W. D., M. K. Hagedorn, T. R. Bardinelli \& R. M. Zablotowicz, 1985. New selective media for the enumeration and recovery of fluorescent pseudomonads from various habitats. Applied Environmental Microbiology 49: 28-32.

Kolb, W. \& P. Martin, 1988. Influence of nitrogen on the number of $\mathrm{N}_{2}$-fixing and total bacteria in the rhizosphere. Soil Biology and Biochemistry 20: 221-225.

Liljeroth, E., J. A. van Veen \& H. J. Miller, 1990. Assimilate translocation to the rhizosphere of two wheat cultivars and subsequent utilization by rhizosphere microorganisms at two soil nitrogen concentrations. Soil Biology and Biochemistry (in press).

Martin, J. K., 1975. Comparison of agar media for counts of viable soil bacteria. Soil Biology and Biochemistry 7: 401-402.

Merckx, R., A. Dijkstra, A. den Hartog \& J. A. van Veen, 1987. Production of root-derived material and associated microbial growth in soil at different nutrient levels. Biology and Fertility of Soils 5: 126-132.

Merckx, R., J. H. van Ginkel, J. Sinnaeve \& A. Cremers, 1986. Plant-induced changes in the rhizosphere of maize and wheat. I. Production and turnover of root-derived material in the rhizosphere of maize and wheat. Plant and Soil 96: 85-93.

Miller, H. J., E. Liljeroth, G. Henken \& J.A. van Veen, 1990. Fluctuations in the fluorescent pseudomonad and actinomycete populations of rhizosphere and rhizoplane during the growth of spring wheat. Canadian Journal of Microbiology 36: 254-258.

Turner, S. M., E. I. Newman \& R. Campbell, 1985. Microbial populations of ryegrass root surfaces: Influence of nitrogen and phosphorus. Soil Biology and Biochemistry 17: 711-715.

Veen, J. A. van, R. Merckx \& S. C. van de Geijn, 1989. Plant and soil related controls of the flow of carbon from roots through the soil microbial biomass. Plant and Soil 115: 179-188.

Vuurde, J. W. L. van, 1978. The rhizosphere microflora of wheat grown under controlled conditions. I. The effect of soil fertility and urea leaf treatment on the rhizoplane microflora. Plant and Soil 50: 447-460.

Vuurde, J. W. L. van \& A. de Lange, 1978. The rhizosphere microflora of wheat grown under controlled conditions. II. Influence of the stage of growth of the plant, soil fertility, and leaf treatment with urea on the rhizosphere microflora. Plant and Soil 50: 461-472.

Whipps, J. M.\& J. M. Lynch, 1986. The influence of the rhizosphere on crop productivity. Advances in Microbial Ecology 9: 187-244. 